\title{
THE MYTH OF EROS IN MICHAEL FIELD'S SAPPHIC PROJECT: FROM A NEW MATERIALISM TO A TRAGIC DETERMINISM
}

\author{
MAYRON ESTEFAN CANTILLO LUCUARA \\ Universitat de València
}

\begin{abstract}
The purpose of this paper is to examine how Katharine Bradley and her niece Edith Cooper reinterpret the figure of Sappho in direct connection with the myth of Eros in Long Ago (1889), their first volume of lyrics written under the pen name of Michael Field. To this end, I select a series of poems addressed to the Greek deity of love, offer a close reading thereof, and prove that the Fields compose a dramatic mythography that explores the god's paradoxical identity and, in so doing, reveals a timeless truth contained in the very essence of the Eros myth: love is an ambivalent phenomenon that creates, inspires and elevates as much as it destroys, oppresses, and kills.
\end{abstract}

Keywords: Michael Field, Long Ago, Sappho, Eros, paradox, myth.

\section{EL MITO DE EROS EN EL PROYECTO SÁFICO DE MICHAEL FIELD: DE UN MATERIALISMO NUEVO A UN DETERMINISMO TRÁGICO}

\begin{abstract}
Resumen
El objetivo de este artículo consiste en examinar cómo Katharine Bradley y su sobrina Edith Cooper reinterpretan la figura de Safo en conexión directa con el mito de Eros en Long Ago (1889), el primer poemario que compusieron bajo el pseudónimo de Michael Field. Con este propósito en mente, seleccionamos una serie de poemas dirigidos a la deidad griega del amor, realizamos un análisis detallado de los mismos y demostramos que las Fields componen una mitografía dramática que explora la identidad paradójica del dios y, al mismo tiempo, revela toda una verdad intemporal inherente al propio mito de Eros: el amor constituye un fenómeno ambivalente que crea, inspira y eleva tanto como destruye, oprime y mata.
\end{abstract}

Palabras clave: Michael Field, Long Ago, Safo, Eros, paradoja, mito. 
120 Mayron Estefan Cantillo Lucuara The Myth of Eros in Michael Field's Sapphic...

\section{INTRODUCTION}

Canadian scholar and poet Anne Carson starts off her first published work with a short yet precise formulation of the idea she wishes to explore in depth: "Eros seemed to Sappho at once an experience of pleasure and pain. Here is contradiction and perhaps paradox» (Carson, 1986: 18). I take these words as the starting point of this study, which also seeks to examine how the ancient myth of Eros is dramatised and represented as an unsolvable paradox in the first volume of lyrics that Katherine Bradley and her niece Edith Cooper published under the pen name of Michael Field in 1889. The volume, entitled Long Ago, appropriates a large corpus of fragmentary poems attributed to Sappho and amplifies them into what Evangelista (2009: 102) defines as "an imaginative biography» of the Lesbian poetess. The Fields, as Bradley and Cooper were jointly called by their peers, approach Sappho as an open myth with virtually no historical identity and transform her into a psychologically complex character and even an irremediably tragic heroine.

In Greek mythology, the figure of Eros represents a radical synthesis of polarities that defies any model of dualistic logic. On the one hand, in different archaic and classical legends, Eros is a primordial deity, a guarantor of Cosmos, and even the very origin and preserver of creation ${ }^{1}$. For some of the partakers in Plato's Symposium, Eros embodies virtue, good, delicacy, tenderness, beauty, strength, vitality, and poetic grace. For Diotima of Mantinea, who Socrates identifies in the banquet as one of his mentors, love is a driving force that makes us look for beauty in every possible form and whose power, if wisely deployed, can lead us to a rich spiritual and intellectual life primarily invested in knowledge and philosophy. However, Diotima adds a minor yet significant detail regarding the genealogy of Eros: he descends from Poros (abundance) and Penia (poverty) ${ }^{2}$. He represents a series of extreme oppositions at once-plenitude and lack, satisfaction and longing, or even creation and

\footnotetext{
${ }^{1}$ According to Smith (1876: 50), Hesiod is the earliest author that mentions Eros and "describes him as the cosmogonic Eros. First, says Hesiod, there was Chaos, then came Gea, Tartarus, and Eros, the fairest among the gods, who rules over the minds and the council of gods and men».

${ }^{2}$ See Plato's Symposium (1925: sec. 178).
} 
destruction. Indeed, there is a dark side to Eros that makes him a terrifying, treacherous and fatal divinity. As Bruce S. Thornton (1997: 7) sums it up, ancient Greek literature abounds with a solid «imagery of fire, war, disease, insanity, and death» that locates Eros «in the realm of destructive nature». Eros conquers, subordinates, alienates, harms and even kills anyone-God or mortal- that falls irrationally under his sway.

Sappho is well known for her special connections with the figure of Eros. Many of her fragments, as Page DuBois (2015: 12) explains, address the complex phenomenon of love generally «as a trouble, a scourge, a stimulant to madness, not the gentle and benign rule of a kindly cupid». DuBois goes on to claim that, for Sappho, Eros incarnates a radical ambivalence: "he can cause terrible pain as well as desire and its gratification, suffering that comes from yearning and desire» (DuBois, 2015: 12). According to legend, Sappho falls prey to this tragic ambivalence in her own flesh when she meets a handsome boatman named Phaon, becomes smitten with him, only receives his coldest indifference, and eventually resolves to take her own life by jumping off a cliff ${ }^{3}$. «This Sappho,» writes DuBois (2015: 108), «is the one bequeathed for posterity, for many centuries the definitive, forlorn, love-struck and suicidal poet».

In their Long Ago (1889), written under the pseudonym of Michael Field, Katharine Bradley and Edith Cooper devote an extensive part of the volume to the Sapphic legend of tragic love and a small yet significant portion to the figure of Eros as the causal agent behind Sappho's fatal desire. So far most critics have neglected to explore these aspects of Long Ago in favour of a hermeneutic reading particularly focused on how the volume mirrors its authors' sexual identity, articulates a highly suggestive language of female homoerotic desire, and thus portrays Sappho as the most classical model of lesbianism ${ }^{4}$. However, although this line of interpretation may well be accurate and convincing, it takes no heed of the fact that Long Ago is fundamentally constructed as a mythopoetic

${ }^{3}$ The most popular and fertile account of this romantic myth is the Ovidian epistle written in Sappho's name and dedicated to her lover Phaon. See Ovid's Epistulae (1907: $\mathrm{XV})$.

${ }^{4}$ See Leighton (1992), White (1990, 1996a, 1996b), Prins (1999), Reynolds (2003), Thain (2007), Madden (2008), Primamore (2009), Evangelista (2009), Olverson (2009), CantilloLucuara (2018a). 
text that reinvents the Sapphic archetype of erotic yet tragic poet and, in so doing, puts Sappho in dialogue with different classical myths for the eventual purpose of creating a coherent mythology of desire, suffering, and death. ${ }^{5}$ In this essay, I examine and demonstrate how such a dialogue incorporates the mythic figure of Eros as an essential interlocutor in seven different lyrics and how his presence transforms Long Ago into a dramatic yet cogent inquiry into the power and tragedy of love.

\section{THE OMNIPOTENCE OF EROS: RETHINKING MATERIALISM}

In Long Ago, Bradley and Cooper explore the phenomenon of love in Sappho's reconstructed life from a complex perspective that seeks to revise the classical myth of Eros in different ways. Their exploration results in what could be read systematically as an entire ars amatoria through a short yet consistent cycle of lyrics that invoke the divine figure of Eros, revalue the mythological values of this deity, and formulate an ambivalent erotic phenomenology (a treaty that reveals how love manifests itself essentially as an unsolvable and open paradox).

In poem VIII, Michael Field's new Sappho composes a passionate ode arguing for an implicit philosophy that understands life as an erotic and aesthetic process. The kernel of this philosophy resides in an omnicomprehensive principle of pleasure that displaces any traditional schism between the subject and the object world, invalidates the very doctrines of classical epistemology, and instead provides an alternative model of subject/object interaction predicated not on knowledge or cognition, but on an erotic form of dwelling in the world -or a way of experiencing and changing the world through the mediation of love itself-. The poem reads:

WITH love nor languorous nor vain,

I prize, in their degrees,

The perfect odour, the red fruit

Ungathered on the trees;

The broidered strap of Lydian work

${ }^{5}$ For a detailed study on other classical myths in Long Ago, see Cantillo-Lucuara (2018b). 
That Gorgo's foot doth deck,

The strings of tender garlands twined

About her tender neck:

The feel of fine-wove linen

When the limbs spring to pass

In lightsome dance bare-footed

Trampling the blooms of grass;

The pressure of the cushion,

The golden goblet bright,

The bubbles of the wine-draught-

Each thrills me with delight:

For each of them brings honour,

Being delicate to sense,

To the beauty of the body,

And to Love's omnipotence.

Love has to me the splendour,

The glory of the sun;

And the least action 'neath his eye

Must be divinely done (ll. 1-24).

The opening words of poem VIII encapsulate the foundational precept of Sappho's erotic phenomenology in what appears to be a mere prepositional phrase - «WITH love» (l. 1). Sappho's experience of the world involves an intimate bond with it that is based on love, care and pleasure. The capital preposition indicates the function of mediation and connection that the primary noun fulfils in such a relationship with the object world. Love opens and exposes Sappho to the world: it renders her sensitive and susceptible to what she describes as an aesthetic world of delicacy. Love acquires a world-making significance and becomes a mechanism of what Martin Heidegger would call «world-disclosure» in the sense that it reveals or discloses the world to Sappho in the most precious and divine manner ${ }^{6}$. In this sense, love transforms the world not just into an object of experience, but into an aesthetic experience in itself.

${ }^{6}$ For Heidegger (1962: 176), the agency of Eros would equate to an essential mood or Stimmung that "discloses, in every case, being-in-the-world as a whole and makes it possible first of all to direct oneself towards something». In other words, as the Fields theorise in their lyrics, love becomes the necessary pre-condition for our access to the world: it makes the world accessible, significant, and even liveable. 
Put otherwise, Sappho apprehends the world as a lived form of erotic aestheticism through the agency of love.

Sappho makes it clear from the outset that the kind of love she advocates is neither "languorous nor vain» (1. 1). These attributes seem to serve as a justification for the type of her loved objects, which do not represent special entities, elevated concepts, sublime artworks or disdainful beloveds. Instead, what Sappho most treasures are little and simple objects that, their simplicity notwithstanding, arouse in her a love that is not frivolous, senseless or even hurtful, but one that prizes each object for its aesthetic value. In poem VIII, the enumeration of such objects unfolds a heterogeneous listing that ranges from natural goods to the most artificial ornaments and jewels. Every fragrance becomes a "perfect odour» (1. 3). Royal fabrics, decorative garlands and «fine-wove linen» (1. 9) appear all together as symbols of female beauty that refer to the Spartan queen Gorgo's delicacy, sensuality and tenderness. On the other hand, the footsteps, which devastate Sappho's erotic landscape in poem $\mathrm{V}$, are now feet dancing and trampling the grass gently ${ }^{7}$. The action of trampling, far for violent and destructive, now connotes a grace that finds its own music in the long alliteration between the words "pass» (l. 10), «dance» (l. 11), and "grass» (l. 12). Based on these sounds, the music to which the feet are dancing is not a threnody or a tragic song, but a gentle and lightsome one. The whole scene, in contrast to the barren landscapes where Sappho despairs and cries for her beloved, constitutes a bucolic and utopian setting.

Poem VIII continues to deal with the effects of love upon Sappho's world. "The pressure of the cushion» (1. 13) shares its delicacy with the lightsome trampling of the grass, marks a stark difference with regard to the affective oppression Sappho feels in other songs, and suggests an intimate rapport with the world reduced to the cushion she holds. The last two images of the enumeration - «the golden goblet» (l. 14) and «the bubbles of wine» (1. 15)- form an aesthetic picture of subtle inebriation and sensual Dionysianism that brings poem VIII to its zenith of sensuality, carnality and pleasure. In the process of this long listing of prized experiences, one is led to imagine Sappho being eroticised and

\footnotetext{
${ }^{7}$ In poem V, Sappho likens herself to a trampled hyacinth that withers and dies in a somber and infertile landscape crushed by shepherds with their most callous footsteps.
} 
seduced by the world she is describing. Her interaction with it is not contemplative, rational, passive, detached and framed by the traditional dualism between object and subject. Instead, she involves herself in a sensual objectivity, engaging erotically with it, living its beauty, and feeling its delicacy. The world's odours, feels, pressures and pleasures are not mere objective phenomena or stand-alone entities. Sappho acts and behaves lovingly towards them. Her intentionality or connection to the outer world is erotic. Her consciousness is not just consciousness of the world as res extensa: it is an erotic consciousness that transcends the object/subject divide and synthesises both poles into a joint experience of pleasure and thrilling delight. In her world, Sappho feels that each object «thrills me with delight» (l. 16).

After the long enumeration of loved objects, Sappho clarifies why she celebrates them with such fervency: «For each of them brings honour, / Being delicate to sense, / To the beauty of the body, / And to Love's omnipotence» (ll. 17-20). It is their delicacy that makes the objects so valuable and even erotic. Naturally, the sense of delicacy is not notional or conceptual at all: rather, it implies the immersion of the Sapphic subject in the direct enjoyment of every object. From a phenomenological viewpoint, this immersion constitutes an experience of exchange between subject and object in which a phenomenon or effect of reversibility takes place: the subject acts not only as a sentient agent that feels such delicacy, but also as a sensible receptor of such delicacy. Here the relationship is two-faced: subject and object interchange their positions and transform the experience of delicacy into a paradigmatic form of dual encounter that can only occur when subject and object deal with one another and confuse themselves into one another. In this sense, the phenomenon of delicacy could be seen as a counter-dualistic experience that entails the very dissolution of a loving consciousness and a loved objectivity ${ }^{8}$.

${ }^{8}$ Implicit in this explanation is the idea of reversibility that Maurice Merleau-Ponty presents in his study Le visible et l'invisible (1964). Here the French thinker turns to the rhetorical trope of the chiasmus to transform it into an ontological formula «of capturing his understanding of flesh and the reversibility of touching/touched or of the visible and the invisible» (in Landes 2013: 38). Through such a formula Merleau-Ponty posits an ontological theory that resists every form of binarism between activity and passivity, seeing and being seen, touching and being touched, or feeling and being felt, in favour of an 
In the reversible experience of delicacy, the body is necessarily involved and impacted, and in poem VIII it acquires an elevated place of honour. The delicacy of the prized objects not only engages the sentient subject in a non-binary exchange: it brings "honour $[\ldots]$ to the beauty of the body" (ll. 17 and 19). In feeling such delicacy, the body enhances its beauty, amplifies the effects of the object world on Sappho, and thus renders the subject/object encounter more meaningful and aesthetic. However, what may be more striking here is the "honour» given to the body itself. Conventionally, the semantic spectrum of «honour» covers such aspects as human character, intellect, respect, religious piety, and even female chastity. In poem VIII, what deserves honour is the body itself or the flesh as opposed to human virtue and spirit. This entails a possible oxymoron that conflates the corporeal or material with the mental and the spiritual. As a result, Sappho proposes a revised notion of materialism that dismantles the normative schism between mind and matter in a way that elevates the status of the body as a transcendental figure of beauty, delicacy and honour.

The transcendental status that Sappho ascribes to the body in its contact with a beautiful and delicate world stems from what she names «Love's omnipotence» (l. 20). This particular line is central to her phenomenology of Eros. Sappho treats love not as a mere notion or abstraction: she capitalises its name, invokes its mythical personification and regards it as almighty. In its apotheosis, love reaches the very stature of the sun: "Love has to me the splendour, / The glory of the sun» (ll. 2122). From this supreme position, the deity of love becomes the transformative force behind everything that happens «neath his eye» (l. 23). In this way, love is no longer a sentimental immanence or a mere affective state: it grows into a transcendental event that ennobles and elevates every act «divinely done» (1. 24) in its name. Love becomes the very core of an overarching sacred pragmatics in which the world, if engaged through the phenomenon of love itself, is not just mundane or material: it gains a transcendental value that redefines its nature, now profane and divine at once.

intimate «cross-over or encroachment» between supposed oppositions that, in actual fact, function within a "world that is simultaneously subject and object» (in Landes 2013: 241). 
In poem VIII, which seems to be a short treaty on the power of Eros, the agency of love breaks down the ontological barriers between subject and object, exposes the lyric subject to an affective experience of the world, transforms the phenomenon of delicacy into a reversible one, endows the loved objects with a sense of utmost sensuality, reconceptualises the philosophical status of the body, and even attributes a spiritual significance to the mundane world of matter. Sappho holds such a fervid belief in the transcendental and sacred power of love, that she reasserts it empathically in lyric XXXVI:

YEA, gold is son of Zeus: no rust

Its timeless light can stain;

The worm that brings man's flesh to dust

Assaults its strength in vain:

More gold than gold the love I sing,

A hard, inviolable thing.

Men say the passions should grow old

With waning years; my heart

Is incorruptible as gold,

'Tis my immortal part:

Nor is there any god can lay

On love the finger of decay (ll. 1-12).

In these two sestets, Sappho composes another fervent ode to love in which it acquires the value of gold and surpasses the power of the gods. For Sappho, love resembles gold: it is timeless, solid, unalterable, incorruptible and immortal. Such is its enormous power that no god can act against it. Sappho praises the force of love, feels its immortality within her own heart, and comes to view it as a supra-divine power. Nevertheless, what is particularly suggestive in her affirmative phenomenology of Eros is that Sappho celebrates it with her songs, believes passionately in its absolute supremacy over the whole world (including gods and mortals), and affirms this belief in spite of the fact that she herself is dying of lovelessness. Love impregnates Sappho's existence, subsumes her life under an aestheticism that ennobles every object she contemplates, and even divinises every action taken in its name. Sappho praises this erotic order of the cosmos and declares Eros to be omnipotent, and yet this omnipotence is precisely what condemns 
Sappho to a miserable state of impotence and despair in her confrontation with her beloved's contempt. Love exerts its power against Sappho and transforms her existence not only into an aesthetic modus vivendi, but also into a tragic process of suffering and impeding death, as I am to show below.

\section{The Tragic Determinism of LOVE: EROS AS «FATAL CREATURE»}

In poem XXXI, Sappho makes a critical meta-poetic claim: «Though unbeloved, lovers are all my theme» (l. 6). As she declares, her poetry is inherently and tragically linked to what she lacks. Her verse emanates from an ontological gap, an absence, and a failure. Her songs address love as an experience of loss and hopelessness. In Long Ago, Sappho mostly sings of the tragedy of losing the communal affection of her maidens, loving the wrong beloved, or being loved by the wrong lover. It is Sappho's passion for Phaon that distances her from her fellow maids, isolates her emotionally, and even makes her regret her heterosexual desire ${ }^{9}$. Undoubtedly, her desire for Phaon is doubly blameable: not only does it separate her from her ideal community of women, but it also causes her a permanent agony. There is more to Sappho's tragic phenomenology of Eros, however. As lyric XXIII reveals, the poetess forms part of a triangulation of failed desire: while she loves her disdainful ferryman, the poet Alcaeus is smitten with her yet unable to win her heart ${ }^{10}$.

In poem XXIII, Sappho addresses Alcaeus and notices how his hopeless desire for her transforms his body into a ghostly figure. According to the epigraph of the lyric («To himself he seems»), the poet phenomenalises himself, suspends his pure subjectivity and becomes a despondent object of his own perception. He sees himself dispossessed of his own will and lost in a fragmented body as though he were external to himself:

9 For a close analysis of Sappho's tragic hetero-eroticism, see White (1996b), Primamore (2009) and Cantillo-Lucuara (2018a)

${ }^{10}$ As Williamson (1995) explains, different post-classical sources hold without any serious evidence that Alcaeus is among several ancient male poets «who were said to have been in love with Sappho» (7) and to have composed love poetry in her name. 
LIFT, lover, thy long-shadowed eyne!

Why should thy sleepless lids decline,

Thy breast so deeply sigh?

Seek we the shade of yonder pine,

'Neath which the river flows;

There we the sweet flower-test will try

For healing of thy woes.

Thou mourn'st thy maiden's faith is gone;

Stoop for fair-leaved telephilon;

Woe, if the petals cleave!

But see! sharp-struck thy palms upon,

They leap, they burst, as shoots a star.

Alcaeus, lo! thou must believe

This sign of Love-afar (ll. 1-18).

Sappho describes Alcaeus as a dismembered body. As a result of his hopeless desire, he becomes a tragic synecdoche, a pair of eyes in decline, a breast in pain, and two furious palms that refuse to accept the revelation of the magic flower he holds. It is this flower, known as telephilon, that plays an ambiguous symbolic role: it functions as a prophetic talisman, unveils the very truth of love, serves to connect lover and beloved within an imaginary setting of affective verification, reads into the beloved's heart, and exposes what the lover cannot discover by his own means. However, the imaginary encounter with the beloved fails altogether as soon as the magic flower reveals the factual absence of the beloved and the lack of romantic reciprocity. In this manner, the flower confirms the meaning of its own name: the beloved is nothing but a «Love-afan»-a remote and inaccessible object of desire that will always be far and out of reach. This inaccessibility affects both Sappho and Alcaeus in equal measure: she dies for her distant Phaon, and so does he for his unattainable Sappho. Both poets partake of the communal «we» that appears twice in the first stanza of poem XXIII and that unites the two of them in their common experience of love as an unendurable absence.

Sappho pities Alcaeus, empathises with him, and places the blame for their suffering on the double identity of Eros. In poem XXVIII, Sappho defines love in oxymoronic terms, bemoans the curse of romantic 
solipsism, and foresees that, as with her, Alcaeus will endure the pain and death that accompany unrequited love:

LOVE, fatal creature, bitter-sweet,

For my Alcaeus I entreat.

Should I not plead?

To wasting fires

A secret prey I live,

Yet, Eros, that which he desires

I cannot give.

Who shall deliver him? Lo, I,

For love of whom he soon will die,

Weep through the starry night oppressed

That he should love in vain.

Ah, can another mortal breast

Learn Sappho's pain! (1l. 1-13).

Sappho apostrophises the deity of love and accuses him of incarnating a cruel paradox: for he creates and thrills just as much as it destroys and kills. His most idiosyncratic attribute is the bitter-sweetness that Sappho coined in one of her original fragments for the first time in Western literary history ${ }^{11}$. Eros has the double faculty of enlivening our existence and also dooming us to a tormented death. As Michael Field's Sappho rightly claims, love is "a fatal creature» (1. 1) that can either create a blissful life or cause an irreversible fatality. The fatality that befalls Sappho and Alcaeus lies in that their erotic vitality is going to waste. Both poets live a desire that is fulgent and excessive, yet its excess only meets with objective hostility and unresponsiveness. Sappho wastes her erotic vitalism on an indifferent Phaon. Alcaeus, for his part, wastes all his love on a Sappho that claims to be unable to reciprocate his desire: «that which he desires / I cannot give» (ll. 6-7). For both Alcaeus and Sappho, love amounts to an experience of waste, dissipation, and exhaustion, like a fire that remains self-contained, propagates outwardly in vain, and returns to itself rejected, unaltered and exhausted. In the first

11 According to Catherine Maxwell (2001: 32), Sappho is «one of the first poets to describe the heightened emotional quality of relationships and her characterisation of the oxymoronic bitter-sweetness of love has pervaded lyric poetry ever since». 
stanza of poem XXVIII, Sappho employs a precise metaphor: the flames of love are nothing but «wasting fires» (1. 4).

Sappho laments over the love Alcaeus feels towards her and wishes to deliver him from such an oppressive feeling. Her concern for him is based on her own tragic experience of love: she knows very well that «he soon will die» (l. 9) if he persists in his quest to love her. Sappho understands that loving someone ultimately unattainable can lead to a pain that borders too closely on a direct encounter with death. In effect, it is from this mortal pain that Sappho wants to liberate Alcaeus, for she knows that his love of her could place him eventually in the position of ontological loss and agony she inhabits because of Phaon's contempt.

In the third stanza, Sappho does value what Alcaeus grew to feel for her in a positive light, as she remembers her first encounter with him as a memory of joy:

When once his feet to me did stray,

He would forget the homeward way;

And when he gazed I turned to greet

The grace within his eyes;

With love it is such joy to meet

In any guise (ll. 14-19).

Here the lyric voice narrates a scene of romantic infatuation and instantaneous desire. As Sappho recounts, Alcaeus once changed his usual route and lost his sense of direction at the sight of her beloved Sappho. She greeted him and saw in his gaze the pure grace of love. The meeting with him and his love, as she recalls, was a truthful moment of bliss, but this same moment represented the very genesis of suffering and death. The gaze of love is the foundation both of pleasure and pain. In his gaze Alcaeus founded his love of Sappho. His gaze transformed her into his most desired object, and yet it was this gaze that inaugurated his torments. His gaze unveiled a desire that was to fail and cause him extreme agony. His gaze, initially filled with grace, soon had to perceive and face the disgrace of Sappho's rejection.

As the last stanza of poem XXVIII explains, it seems that Alcaeus no longer finds any joy in love. Sappho implores the Muses to help and liberate him from the severe pain that oppresses him to the point of 
silencing his poetic voice. His experience of love is altogether destructive: it threatens to leave him dumb and moribund. Sappho knows that without his poetry and music Alcaeus will inevitably die. His death is always already a certain possibility due to the ominous presence of a vain desire:

To him, O heavenly Muses, come!

He cannot live if he be dumb.

Leave me awhile. O let him feel

His heart set free in song;

Hasten, for ye alone can heal

A lover's wrong (1l. 20-25).

Later on, in lyric XXX, Sappho shows a solid understanding of what love must signify to her fellow poet Alcaeus and even takes delight in his presumably sentimental poetry, but she then justifies why she rejects him: it is not only that she surpasses him in age, but also her greater experience dictates that love is always a vain and painful undertaking. For this reason, she asks her unfortunate lover to forget her and renounce the pursuit of love for his own sake:

THINE elder that I am, thou must not cling

To me, nor mournful for my love entreat:

And yet, Alcaeus, as the sudden spring

Is love, yea, and to veiled Demetia sweet.

Sweeter than tone of harp, more gold than gold

Is thy young voice to me; yet, ah, the pain

To learn I am beloved now I am old,

Who, in my youth, loved, as thou must, in vain (ll. 1-8).

This short poem perfectly defines what might be understood as the tragic determinism of love in Long Ago. In this volume, the identities of beloved and lover are negatively determined and fixed in Sappho's treatment of Eros. The lover always suffers, remains mournful, and actualises the very real possibility of death. The beloved, on the other hand, represents an impossible object, a severe absence and even an agent of ontological nullity for the desperate lover. As a result, Long Ago rests upon a consistent and recurrent idea: Eros is an experience of joy that, nevertheless, facilitates the actualisation of the possibility of death 
when the beloved is nothing but a delusion, a fantasy and a mere hypothetical object.

In the very final lyric of the volume, right before the epilogic poem, Sappho addresses the god of love directly and encapsulates his contradictory identity in a single sestet:

THOU burnest us; thy torches' flashing spires,

Eros, we hail!

Thou burnest us, Immortal, but the fires

Thou kindlest fail:

We die,

And thine effulgent braziers pale (ll. 1-6).

Eros is the immortal fire of life, as Sappho asserts here. He burns us in the sense that he motivates, enlivens, ignites and kindles our life. $\mathrm{He}$ acts essentially as the biological and psychical force of our selfpreservation and existence. However, Sappho realises that such a vital force fails and succumbs to death itself. Eros meets with his radical other in the shortest line that Michael Field writes in Long Ago: «We die» (1.5). Love proves to be fallible and self-contradictory: it kindles life and yet destroys it in equal measure. It burns not only in a vital and positive sense, for its flames can also consume and kill. Sappho concludes poem LXVIII by revealing in a few words how the power and failure of love burnt her into ashes: «I, Eros! am quenched within my urn» (1. 24).

\section{CONCLUSIONS}

In the lyrics I have analysed above, the Fields carry out a double appropriation of the Greek past by revising the Sapphic archetype in light of the myth of Eros. The result of this twofold revision is a mythographic Long Ago that establishes a dialogue between the Lesbian lyrist and the deity of love in a dramatic and complex way. Indeed, the complexity of this dialogue resides in how Michael Field's Sappho addresses Eros through a dramatic discourse that reveals the god's contradictory identity. On the one hand, Eros appears in a positive light as the originator of a world that becomes aesthetic, attractive, and immensely meaningful under his omnipotent regime. In such a utopian world, 
Sappho experiences life in a direct and intimate manner, with no epistemological barriers between subject and object, and with a new philosophy of the body, which ceases to be a defective and inferior form of matter and becomes a transcendental figure of spiritualised pleasure and honour. This Sapphic experience of the world is entirely mediated and made possible by the agency of Eros, who proves to be a source of dignity and beauty for everything and everybody standing under his supra-divine power.

Nevertheless, it seems that Sappho's ode to Eros is merely based on a theoretical or philosophical perspective that celebrates the deity's cosmic potential. In her actual experience, Sappho knows an altogether different kind of Eros, one that equates love to loss and condemns the unrequited lover to an acute anxiety, a ghostly existence, and a gradual encounter with death. In Long Ago, Sappho and her fellow poet Alcaeus are victims of this tragic romanticism that not only destroys their ontological independence, but even threatens to silence them and incapacitate them as poets.

What results from Michael Field's reworking of the Eros myth in dialogue with the figure of Sappho is the crudest confirmation of a timeless truth that stems from the essence of myth, which, far from primitive and merely fictive, entails a transcendental and existential message on the nature of human emotions in general and of love in particular. Indeed, the myth of Eros functions infallibly as a transhistorical truth that conceptualises how we, whether Ancients or Moderns, experience love as a blessing and a tragedy at once ${ }^{12}$.

12 Here I take my cue from O'Gorman's reading of Long Ago (2016: 650), which emphasises the value of myths in the volume and acknowledges their ability to express «a universal sense of human emotions». 


\section{BIBLIOGRAPHY}

Cantillo-Lucuara, M.E. (2018a): «Michael Field's Sapphism: An Ontology of the Feminine in Long Ago (1889)». Lectora: Revista de dones i textualitat, 24, pp. 205-222.

— (2018b): «Michael Field's Long Ago (1889): A Transcendental Mythopoesis of Desire and Death». ES Review. Spanish Journal of English Studies, 39, pp. 69-96.

CARson, A. (1986): Eros the Bittersweet: An Essay. Princeton, PUP.

DuBoIs, P. (2015). Sappho. London-New York, I.B. Tauris.

Evangelista, S. (2009): British Aestheticism and the Ancient Greece: Hellenism, Reception, Gods in Exile. Basingstoke, Palgrave Macmillan.

FIELD, M. (1889): Long Ago. London, George Bell and Sons.

HeIdegger, M. (1962): Being and Time. Trans.: J. Macquarrie and E. Robinson. New York, Harper Perennial.

LANDES, D.A. (2013): The Merleau-Ponty Dictionary. London, Bloomsbury.

Leighton, A. (1992): Victorian Women Poets: Writing Against the Heart. New York, Harvester Wheatsheaf.

Madden, E. (2008): Tiresian Poetics: Modernism, Sexuality, Voice, 1888-2001. Madison, Fairleigh Dickinson UP.

MaXwell, C. (2001): The Female Sublime from Milton to Swinburne: Bearing Blindness. Manchester, MUP.

O'Gorman, F. (2016): «Michael Field and Sapphic Fame: My Dark-Leaved Laurels Will Endure». Victorian Literature and Culture, 34.2, pp. 649-661.

Olverson, T.D. (2009): «Libidinous Laureates and Lyrical Maenads: Michael Field, Swinburne and Erotic Hellenism». Victorian Poetry, 47.4, pp. 759-802. Ovid (1814): The Epistles of Ovid. Trans. and ed.: J. Nunn, R. Priestly, R. Lea, and J. Rodwell. Perseus Digital Library (on-line: <perseus.tufts.edu/hopper/t ext?doc=Perseus\%3Atext\%3A1999.02.0085\%3Apoem\%3D15> [accessed: 15 April 2019]).

Plato (1925): «Symposium». Plato in Twelve Volumes, Vol. 9. Trans.: H.N. Fowler. Cambridge (MA), Harvard UP.

Primamore, E.A. (2009): «Michael Field's Sapphic Communities: Constructing the Transgressive Feminine Sensibility in Long Ago (1889)». The Michaelian, 1 (on line: <thelatchkey.org/Field/MF1/primamorearticle.htm> [accessed: 18 April 2019]).

PRINS, Y. (1999): Victorian Sappho. Princeton, PUP.

REYNOLdS, M. (2003): The Sappho History. Basingstoke, Palgrave Macmillan. 
136 Mayron Estefan Cantillo Lucuara The Myth of Eros in Michael Field's Sapphic...

Thain, M. (2007): 'Michael Field' Poetry, Aestheticism, and the Fin de Siècle. Cambridge, CUP.

Thornton, B.S. (1997): Eros: The Myth of Ancient Greek Sexuality. Oxford, Westview Press.

Smith, W. (1876): Dictionary of Greek and Roman Biography and Mythology Vol. II. London, John Murray.

White, C. (1996a): «The Tiresian Poet: Michael Field». In: Leighton A. (ed.), Victorian Women Poets: A Critical Reader. London, Blackwell, pp. 148-161.

- (1996b): «Flesh and Roses: Michael Field's Metaphors of Pleasure and Desire». Women's Writing, 3.1, pp. 47-62.

— (1990): «Poets and Lovers Evermore: Interpreting Female Love in the Poetry and Journals of Michael Field». Textual Practice, 4.2, pp. 197-212.

Williamson, M. (1995): Sappho's Immortal Daughters. Cambridge (MA), Harvard UP.

Mayron Estefan CANTILLO LuCUARA Universitat de València Mayron.Cantillo@uv.es 0000-0002-1298-8496 